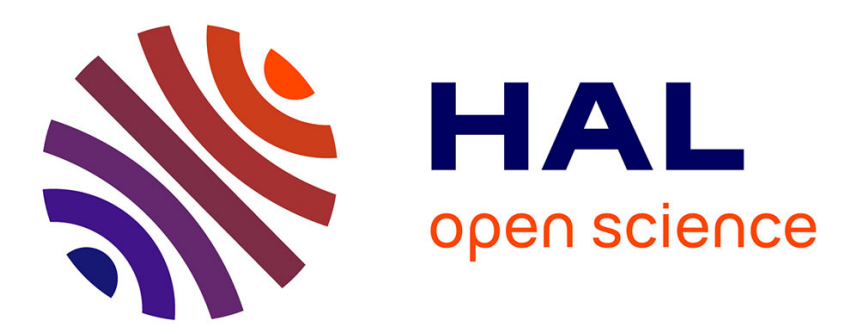

\title{
Synthesis and antitumor activity of benzils related to combretastatin A-4
}

Céline Mousset, Anne Giraud, Olivier Provot, Abdallah Hamze, Jérôme

Bignon, Jian-Miao Liu, Sylviane Thoret, Joëlle Dubois, Jean-Daniel Brion, Mouâd Alami

\section{To cite this version:}

Céline Mousset, Anne Giraud, Olivier Provot, Abdallah Hamze, Jérôme Bignon, et al.. Synthesis and antitumor activity of benzils related to combretastatin A-4. Bioorganic and Medicinal Chemistry Letters, 2008, 18 (11), pp.3266-3271. 10.1016/j.bmcl.2008.04.053 . hal-02394592

\section{HAL Id: hal-02394592 https://hal.science/hal-02394592}

Submitted on 4 Dec 2019

HAL is a multi-disciplinary open access archive for the deposit and dissemination of scientific research documents, whether they are published or not. The documents may come from teaching and research institutions in France or abroad, or from public or private research centers.
L'archive ouverte pluridisciplinaire HAL, est destinée au dépôt et à la diffusion de documents scientifiques de niveau recherche, publiés ou non, émanant des établissements d'enseignement et de recherche français ou étrangers, des laboratoires publics ou privés. 


\title{
Synthesis and anti-tumor activity of benzils related to combretastatin A-4
}

\author{
Céline Mousset, ${ }^{\mathrm{a}}$ Anne Giraud, ${ }^{\mathrm{a}}$ Olivier Provot, ${ }^{\mathrm{a}}$ Abdallah Hamze, ${ }^{\mathrm{a}}$ Jérôme Bignon, ${ }^{\mathrm{b}}$ Jian-Miao \\ Liu, ${ }^{\mathrm{b}}$ Sylviane Thoret, ${ }^{\mathrm{b}}$ Joëlle Dubois ${ }^{\mathrm{b}}$ Jean-Daniel Brion, ${ }^{\mathrm{a}}$ and Mouâd Alami ${ }^{\mathrm{a}, *}$ \\ ${ }^{a}$ Univ Paris-Sud, CNRS, BioCIS-UMR 8076, Laboratoire de Chimie Thérapeutique, Faculté de Pharmacie, rue J. B. Clément F-92296 \\ Châtenay-Malabry, France. \\ ${ }^{\mathrm{b}}$ Institut de Chimie des Substances Naturelles, UPR 2301, CNRS, avenue de la Terrasse, F-91198 Gif sur Yvette, France.
}

\begin{abstract}
A series of benzil derivatives related to combretastatin A-4 (CA-4) has been synthesized by oxidation of diarylalkynes promoted by $\mathrm{PdI}_{2}$ in DMSO. Using this new protocol, 14 benzils were prepared in good to excellent yields and their biological activity has been delineated. Several benzils exhibited excellent antiproliferative activity: for example, $\mathbf{4 j}$ and $\mathbf{4 k}$ bearing the greatest resemblance to CA-4 and AVE-8062 respectively were found to inhibit cell growth at the nanomolar level (20-50 nM) on four human tumor cell lines.

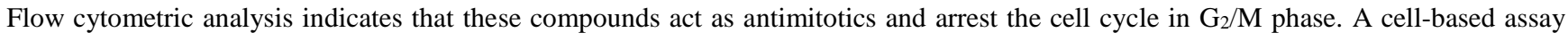
indicated that compounds $\mathbf{4} \mathbf{j}$ and $\mathbf{4 k}$ displayed a similar inhibition of tubulin assembly with an $\mathrm{IC}_{50}$ value similar to CA-4. These results clearly demonstrated that the Z-double bond of CA-4 can be replaced by a 1,2-diketone unit without significant loss of cytotoxicity and inhibition of tubulin assembly potency.
\end{abstract}

Microtubules are dynamic structures that play an essential role in cellular functions including motility, division, shape maintenance and intracellular transport. ${ }^{1}$ The discovery of natural and synthetic substances able of interfering with the assembly or disassembly of microtubules has attracted much attention because microtubules are recognized as an attractive pharmacological target for anticancer drug discovery. ${ }^{2}$ Recently, it was demonstrated that some tubulin binding agents also target the vascular system of tumors, inducing morphological changes in the endothelial cells of the tumor blood vessels so as to occlude flow. ${ }^{3}$

Combretastatin A-4 (CA-4, 1a), a natural Z-stilbene isolated from the South African willow Combretum caffrum, ${ }^{4}$ has been found to strongly inhibit the tubulin assembly by binding to the colchicine site ${ }^{5,6}$ and to be a cytotoxic agent ${ }^{6}$ against a wide variety of cell lines, including multidrug resistant lines. Additionally, the disodium phosphate of CA-4 (CA-4P, 1b), a water soluble prodrug, as well as AC-7739 (1c) and its amino acid derivative 1d (AVE-8062) ${ }^{7}$ have been demonstrated to cause reversible vascular shutdown in established tumors in vivo, consistent with an anti- vascular mechanism of action. ${ }^{8}$ Currently, CA4-P $\left(\right.$ Zybrestat $^{\mathrm{TM}}$ ), either as a single agent or in combination therapy is worldwide undergoing several advanced clinical trials for the treatment of age-related macular degeneration $(\mathrm{AMD})^{9}$ or anaplastic thyroid cancer. ${ }^{10}$<smiles>[R]c1cc(/C=C/c2cc(OC)c(OC)c(OC)c2)ccc1OC</smiles>

1a $\mathrm{R}=\mathrm{OH}(\mathbf{C A}-4)$

1b $\mathrm{R}=\mathrm{OP}(\mathrm{O})(\mathrm{ONa})_{2} \quad(\mathbf{C A}-4 \mathrm{P})$

1c $\mathrm{R}=\mathrm{NH}_{2} \quad$ (AC-7739)

1d $\mathrm{R}=\mathrm{NH}-\mathrm{Ser}-\mathrm{H}$ (AVE-8062)<smiles>CCOCCOC</smiles>

Chalcone, 3<smiles>COc1ccc(C(=O)c2cc(OC)c(OC)c(OC)c2)cc1O</smiles>

2 (Phenstatin)
Figure 1. Representative tubulin binding agents and general structure of the synthesized benzils 4 . 
The structural simplicity of CA-4 combined with its excellent antitumoral and antivascular activities encouraged the scientific community to synthesize numerous analogues. ${ }^{11}$ From these structure-activity relationship (SAR) investigations, it has been established that the cis-orientation of the two aryl rings is crucial for the activity of $\mathbf{1}$ as well as the trimethoxyaryl unit, whereas the hydroxyl group on the 3 '-position is not essential. ${ }^{12}$ However, during the storage and administration cis-combretastatin analogues tend to isomerize to trans-forms which show dramatic reduction in both anti-tubulin and cytotoxic activities. Therefore, many studies have focused on the design of analogues by altering the linking group and the B-ring of $\mathbf{1}$ to provide better biological activities. Among these, analogues phenstatin ${ }^{13}(\mathbf{2})$, and chalcone ${ }^{14} \mathbf{3}$ (Figure 1) where the olefinic bridge of CA-4 was replaced by a carbonyl group, or an enone function respectively were identified as potent inhibitors of tubulin assembly and also displayed cytotoxic activities at a nanomolar level $\left(\mathrm{IC}_{50}=0.2\right.$ to $\left.30 \mathrm{nM}\right)$. In an ongoing medicinal chemistry program towards the synthesis of CA-4 analogues ${ }^{15}$ we also were interested in exploring the alteration of the linker and the B-ring. In the present study, introduction of two carbonyl functions between the two aromatic rings leading to benzil derivatives 4 was expected to maintain on one hand, the appropriate two carbon-distance between the aromatic rings and on the other hand, the crucial $\mathrm{sp}^{2}$ hybridation of the two carbon linkers (Figure 1). Furthermore, we envisioned that variation of the substituents on the B-ring would provide significant SAR informations about these CA-4 analogues. The potencies of newly synthesized benzils 4 were evaluated for their capacity to inhibit cancer cellular growth and, to act as potential antimitotic agents as well as for potential apoptosis induction.

The oxidation of substituted diarylalkynes, readily accessible via Sonogashira-Linstrumelle (S-L) coupling, constitutes one of the most versatile processes in organic chemistry for the synthesis of benzils. We recently reported the oxidation of functionalized diarylalkynes with DMSO in the presence of a catalytic amount of the environmentally friendly $\mathrm{FeBr}_{3}$ catalyst. ${ }^{16}$ However, during this study, we observed that substrates containing a heteroaryl nucleus or having a free phenolic or aniline function as well as a nitrile group were resistant to DMSO-oxidation. Herein, we described the use of DMSO-PdI 2 (2 mol\%) couple as a more reliable and chemoselective procedure $^{17}$ to provide functionalized benzils 4 from alkynes 5 . The synthesis of the alkyne precursors $\mathbf{5}$ was achieved by S$\mathrm{L}^{18}$ cross-coupling and Table 1 summarized the results of 5 oxidation with the $\mathrm{PdI}_{2}$-DMSO couple. Accordingly, this procedure conveniently provided a small library of benzil compounds possessing various substituted B-rings even those having a free $\mathrm{OH}$ group (entries 9-10; 4i, 82\%; 4j 86\%). However, with substrate 5k having a free amino group the use of $\mathrm{PdI}_{2}$ was ineffective whereas, $\mathrm{PdCl}_{2}(10 \mathrm{~mol} \%)$ promotes smoothly the oxidation reaction providing $\mathbf{4 k}$ but in low yield $(31 \%$, entry 11$)$. This problem could be easily circumvented by hydrolyzing the acetamido derivative $\mathbf{4 g}$ in alkaline media leading to aniline $4 \mathbf{k}$ in a satisfactory $78 \%$ yield. Finally, under these conditions, alkynes $\mathbf{4 m}$ and $\mathbf{4 n}$ bearing a nitrogen-containing heterocycle, as B-rings, were successfully transformed into their corresponding benzils (entries 13 and 14) with good yields.

Table 1. Oxidation of diarylalkynes 5 to benzil derivatives 4 with the $\mathrm{PdI}_{2}$-DMSO couple.

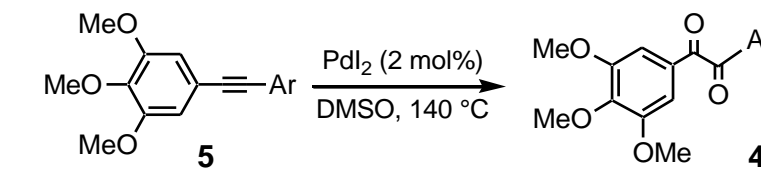

\begin{tabular}{|c|c|c|c|c|}
\hline Entry & Compounds & $\mathrm{Ar}$ & Time (h) & Yield $^{\mathrm{b}}(\%)$ \\
\hline 1 & $4 a$ & & 4 & 62 \\
\hline 2 & $4 b$ & & 12 & 85 \\
\hline 3 & $4 c$ & & 2 & 100 \\
\hline 4 & $4 d$ & & 6 & 93 \\
\hline 5 & $4 e$ & & 14 & 67 \\
\hline 6 & $4 f$ & & 3 & 85 \\
\hline 7 & $4 g$ & & 5 & 83 \\
\hline 8 & $4 h$ & & 4 & 84 \\
\hline 9 & $4 i$ & & 6 & 82 \\
\hline 10 & $4 j$ & & 16 & 86 \\
\hline 11 & $4 k$ & & 5 & $31^{\mathrm{c}}$ \\
\hline 12 & 41 & & 8 & 68 \\
\hline 13 & $4 m$ & & 7 & 70 \\
\hline 14 & $4 n$ & & 94 & 93 \\
\hline
\end{tabular}

a All compounds $\mathbf{4}^{19}$ were unambiguously characterized by spectroscopic (IR, ${ }^{1} \mathrm{H}$ and ${ }^{13} \mathrm{C}$ NMR) techniques. ${ }^{\mathrm{b}}$ Isolated yield. ${ }^{\mathrm{c}} \mathrm{PdCl}_{2}(10 \mathrm{~mol} \%)$ was used instead of $\mathrm{PdI}_{2}$.

In vitro antiproliferative activity of the synthesized 1,2diketones $\mathbf{4}$ was first determined against the human 
colon carcinoma cell line (HCT116) using CA-4 as reference ${ }^{15 b}$ compound, and the results of this study are summarized in Table 2 . The diketone $\mathbf{4 j}$ bearing the greatest resemblance to combretastatin A-4 displays a high activitiy at the nanomolar level $(35 \mathrm{nM})$. This result is very useful and clearly indicates that introduction of a 1,2-dicarbonyl unit between the two aromatic rings maintain good to excellent antiproliferative properties. Interestingly, the corresponding acetate $\mathbf{4 f}$ and compound $\mathbf{4 k}$ related to AVE-8062 have been showed to possess similar interesting antiproliferative activities, indicating that the amino and hydroxyl groups are bioequivalent at the C-3 position of these analogues. By comparison, compounds $\mathbf{4 d}, \mathbf{4 e}$ and $\mathbf{4 g}$ possessing only a methoxy, a dimethoxy or an acetamido substituent retained much of the bioactivity. These results indicate that those 1,2 diketones shared similar SAR with combretastatins reported previously. ${ }^{20}$

Table 2. Cytotoxicities of benzils 4 against human colon carcinoma cell line (HCT116).

\begin{tabular}{l|c|c|c|c|c|c|c|c}
\hline \hline Compound & $\mathbf{4 a}$ & $\mathbf{4 b}$ & $\mathbf{4 c}$ & $\mathbf{4 d}$ & $\mathbf{4 e}$ & $\mathbf{4 f}$ & $\mathbf{4 g}$ & $\mathbf{4 h}$ \\
$\mathrm{IC}_{50} \mathrm{a}(\mathrm{nM})$ & 3000 & $\mathrm{NA}^{\mathrm{b}}$ & $\mathrm{NA}$ & 300 & 300 & 40 & 350 & 700 \\
\hline Compound & $\mathbf{4 i}$ & $\mathbf{4 j}$ & $\mathbf{4 k}$ & $\mathbf{4 l}$ & $\mathbf{4 m}$ & $\mathbf{4 n}$ & $\mathbf{C A - 4}$ \\
$\mathrm{IC}_{50} \mathrm{a}(\mathrm{nM})$ & 2000 & 35 & 38 & 3000 & $\mathrm{NA}$ & $\mathrm{NA}$ & \multicolumn{2}{|c}{1.8} \\
\hline \hline
\end{tabular}

a A sample's concentration which produces a $50 \%$ reduction cell growth. Each drug concentration was tested in triplicate. ${ }^{b}$ Non active.

Table 3. Cytotoxicities of $\mathbf{4 f}, \mathbf{4 j}$ and $\mathbf{4 k}$ against different human cancer cell lines.

\begin{tabular}{lcccc}
\hline \multirow{2}{*}{ Cell line } & \multicolumn{5}{c}{ Compound $\mathrm{IC}_{50} \mathrm{a}(\mathrm{nM})$} \\
\cline { 2 - 5 } & $\mathbf{4 f}$ & $\mathbf{4 j}$ & $\mathbf{4 k}$ & $\mathbf{C A - 4}$ \\
\hline \hline $\begin{array}{l}\text { Human colon carcinoma } \\
\text { (HCT116) }\end{array}$ & 40 & 30 & 38 & 1.8 \\
\hline $\begin{array}{l}\text { Chronic mylogenous } \\
\text { leukemia (K562) }\end{array}$ & 25 & 25 & 20 & 3.6 \\
\hline $\begin{array}{l}\text { Non-small lung human } \\
\text { carcinoma (H1299) }\end{array}$ & 30 & 30 & 50 & 5.0 \\
\hline $\begin{array}{l}\text { Human breast cancer } \\
\text { (MDA-MB231) }\end{array}$ & 40 & 40 & 30 & 3.0 \\
\hline \hline
\end{tabular}

a A sample's concentration which produces a $50 \%$ reduction cell growth. Each drug concentration was tested in triplicate.

Compounds $\mathbf{4 f}, \mathbf{4 j}$ and $\mathbf{4 k}$ that displayed the better cytotoxicity against HCT116 were next evaluated against three different cancer cell lines of diverse origins. The $\mathrm{IC}_{50}(\mathrm{nM})$ values obtained with selected cell lines are summarized in Table 3. Results from the cytotoxicity study provide evidence that benzil derivatives $\mathbf{4 f}, \mathbf{4 j}$ and $\mathbf{4 k}$ are good structural analogues of CA-4. It is noteworthy that all of these compounds retained strong cytotoxic activity (about $30 \mathrm{nM}$ ) against the tested cell lines.
All benzil derivatives 4 prepared above were next evaluated for their ability to inhibit tubulin assembly (Table 4). All samples were dissolved in DMSO, incubated at $37{ }^{\circ} \mathrm{C}$ for $10 \mathrm{~min}$ and at $0{ }^{\circ} \mathrm{C}$ for $5 \mathrm{~min}$ before evaluation of the tubulin assembly rate. Compounds 4 were tested at $\sim 1.3 \times 10^{-4} \mathrm{M}$ and $1.3 \times 10^{-5}$ $\mathrm{M}$. The $\mathrm{IC}_{50}$ was calculated only for compounds inhibiting tubulin assembly by more than $50 \%$ at $1.310^{-}$ ${ }^{5} \mathrm{M}$. The tubulin assembly assay was realized according to a slightly modified Guénard's protocole ${ }^{21}$ using CA-4 as reference compound.

Table 4. Effects on tubulin assembly of benzils 4

\begin{tabular}{llccc}
\hline \hline Entry & Compounds & $\begin{array}{c}\text { \% inhibition } \\
\text { at } 1.310^{-4} \mathrm{M}\end{array}$ & $\begin{array}{c}\text { \% inhibition } \\
\text { at } 1.310^{-5} \mathrm{M}\end{array}$ & $\begin{array}{c}\mathrm{IC}_{50}{ }^{\mathrm{a}} \\
(\mu \mathrm{M})\end{array}$ \\
\hline \hline $\mathbf{1}$ & $\mathbf{4 a}$ & 79 & 34 & - \\
$\mathbf{2}$ & $\mathbf{4 b}$ & 0 & 12 & - \\
$\mathbf{3}$ & $\mathbf{4 c}$ & 28 & - & - \\
$\mathbf{4}$ & $\mathbf{4 d}$ & 89 & 58 & 21 \\
$\mathbf{5}$ & $\mathbf{4 e}$ & 85 & 52 & 63 \\
$\mathbf{6}$ & $\mathbf{4 f}$ & 14 & - & - \\
$\mathbf{7}$ & $\mathbf{4 g}$ & 45 & 45 & - \\
$\mathbf{8}$ & $\mathbf{4 h}$ & 73 & 47 & - \\
$\mathbf{9}$ & $\mathbf{4 i}$ & 69 & 42 & - \\
$\mathbf{1 0}$ & $\mathbf{4 j}$ & 73 & 65 & 1.5 \\
$\mathbf{1 1}$ & $\mathbf{4 k}$ & 88 & 82 & 5.0 \\
$\mathbf{1 2}$ & $\mathbf{4 l}$ & 80 & 23 & - \\
$\mathbf{1 3}$ & $\mathbf{4 m}$ & 23 & - & - \\
$\mathbf{1 4}$ & $\mathbf{4 n}$ & 58 & 35 & - \\
$\mathbf{1 5}$ & $\mathbf{C A - 4}$ & 88 & 77 & 1.0 \\
\hline \hline
\end{tabular}

${ }^{\mathrm{a}}$ Values are means of at least three experiments. ${ }^{\mathrm{b}}$ Concentration inhibiting $50 \%$ of about $2.0 \mathrm{mg} / \mathrm{mL}$ microtubular protein assembly.

Compounds $\mathbf{4 j}$ and $\mathbf{4 k}$, the most closely resembling CA4 and AVE-8062 in structure respectively, displayed potent anti-mitotic activities (entries 10 and 11; 1.5 and $5.0 \mu \mathrm{M}$ respectively). Compound $\mathbf{4 d}$, lacking the $3-\mathrm{OH}$ residue, showed a slight loss of activity compared to $\mathbf{4} \mathbf{j}$ and $\mathbf{4 k}$ as inhibitor of tubulin assembly. Similarly, one can note that the substitution of the C-3 hydroxy group with a methoxy group, to give $\mathbf{4 e}$, had a modest effect on activity as compared to CA-4 (1.0 $\mu \mathrm{M})$. Unfortunately, acetate $\mathbf{4 f}$ which exhibited a significant cytotoxicity against the studied cells line (Tables 2 and 3) was not effective as inhibitor of tubulin assembly. It can be assumed that the acetoxy group is hydrolyzed by esterases in cell what can't happen in the tubulin assay. The lack of activity displayed by the other benzils 4 suggests that modifications of the $\mathrm{B}$ ring disrupt the ligand-protein binding. These variations should prevent the two vicinally related aryl units from adopting the necessary conformation for binding at the colchicine site on tubulin.

The effect of selected compounds $\mathbf{4} \mathbf{j}$ and $\mathbf{4 k}$ on the cell cycle of HCT116 and H1299 cell lines was then investigated by flow cytometry at various concentrations. As shown in Table 5, after $24 \mathrm{~h}$ of 
treatment, a net progression in the number of HCT116 cells arrested at the $\mathrm{G}_{2} / \mathrm{M}$ growth stage was observed with increasing concentration of $\mathbf{4 j}$ and $\mathbf{4 k}$. A similar trend was observed in H1299 cells. Thus, treatment of H1299 cells with $50 \mathrm{nM}$ of $\mathbf{4 j}$ for $24 \mathrm{~h}$ led to $27.7 \%$ of cells arrested at the $\mathrm{G}_{2} / \mathrm{M}$ stage while, at $10 \mathrm{nM}$ only $11.4 \%$ were in this stage.

Table 5. Flow cytometry analysis of compounds $4 \mathbf{j}$ and $4 \mathbf{k}$ in HCT116 and H1299 cancer cells. ${ }^{a}$

\begin{tabular}{lccl}
\hline \hline Compound & $\begin{array}{c}\text { Concentration } \\
(\mathrm{nM})\end{array}$ & $\begin{array}{c}\mathrm{HCT} 116 \\
\left(\% \mathrm{G}_{2} / \mathrm{M}\right)\end{array}$ & $\begin{array}{c}\mathrm{H} 1299 \\
\left(\% \mathrm{G}_{2} / \mathrm{M}\right)\end{array}$ \\
\hline \hline DMSO & - & 11.5 & 8.4 \\
$\mathbf{4 j}$ & 10 & 11 & 11.4 \\
& 20 & 18.5 & 15 \\
& 50 & 22.8 & 27.7 \\
$\mathbf{4 k}$ & 10 & 13 & 11.7 \\
& 20 & 15.9 & 12.2 \\
& 50 & 28 & 16.5 \\
\hline \hline
\end{tabular}

a Data represent percentage of cells in $\mathrm{G}_{2} / \mathrm{M}$ phase of the cell cycle after $24 \mathrm{~h}$ of treatment with $\mathbf{4 j}$ and $\mathbf{4 k}$. Data are representative of three independent experiments.

It should be noted that in all cells treated with $\mathbf{4 j}$ or $\mathbf{4 k}$ for $24 \mathrm{~h}$, a sub-diploid DNA content was observed (data not shown) indicating that cells are undergoing apoptosis probably as a result of the cell cycle being arrested in the $\mathrm{G}_{2} / \mathrm{M}$ phase.

The ability of compounds $\mathbf{4 j}$ and $\mathbf{4 k}$ to induce apoptosis was further characterized by a specific apoptosis assay. Cleavage of pro-caspases to active caspases is one of the hallmarks of apoptosis. HT1299 and HCT116 cell lines were thus treated with 10,50 and $100 \mathrm{nM}$ of compounds $\mathbf{4 j}$ and $\mathbf{4 k}$, then caspases 3 and 7 activities were evaluated using the standard caspase cleavage assays (Figure 2). It was observed after $24 \mathrm{~h}$ of treatment that $\mathbf{4 j}$ and $\mathbf{4} \mathbf{k}$ induced apoptosis in the investigated cell lines. These results show that treatment of cancer cells with compounds $\mathbf{4 j}$ and $\mathbf{4 k}$ activates caspases leading to cellular apoptosis in the same manner as that of CA-4 (data not shown, $466 \%$ at 10 $\mathrm{nM}$ in H1299 cells).

In order to expand our studies, the effects of compounds $\mathbf{4 j}$ and $\mathbf{4 k}$ on the proliferation of human umbilical vein endothelial cells (HUVEC) were determined. The results revealed that, after $72 \mathrm{~h}$ of incubation, compounds $\mathbf{4 j}$ and $\mathbf{4 k}$ exhibit good growth inhibition activity against HUVEC proliferation with an $\mathrm{IC}_{50}$ of 35 and $40 \mathrm{nM}$ respectively ( $\mathrm{IC}_{50} 2.5 \mathrm{nM}$ for CA-4). Additionally, in order to evaluate whether the compound $\mathbf{4 k}$ affects newly formed blood vessels in vitro, the HUVEC tube formation assay was performed. As shown in Figure 3, addition of $4 \mathbf{k}(100 \mathrm{nM})$ to formed cords rapidly disrupted the integrity of the network. This effect was visible after $3 \mathrm{~h}$ of treatment at doses which were not cytotoxic for such incubation time (data not shown). Altogether, our results suggest that these derivatives $\mathbf{4} \mathbf{j}$ and $\mathbf{4 k}$ might be lead compounds for use as antiangiogenic inhibitors.

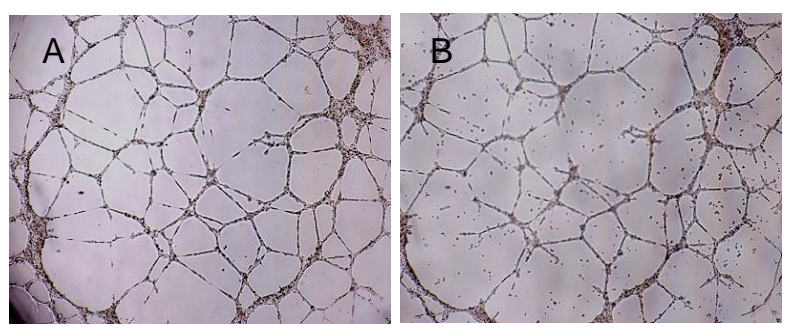

Figure 3. Effects of benzil $\mathbf{4 k}$ on newly formed vessels. In vitro, $\mathbf{4 k}$ or vehicle was added to cords formed by endothelial cells on Matrigel, $24 \mathrm{~h}$ after HUVEC seeding; Images were taken $3 \mathrm{~h}$ after addition of the compound. (A) Control; (B) 4k (100 nM).
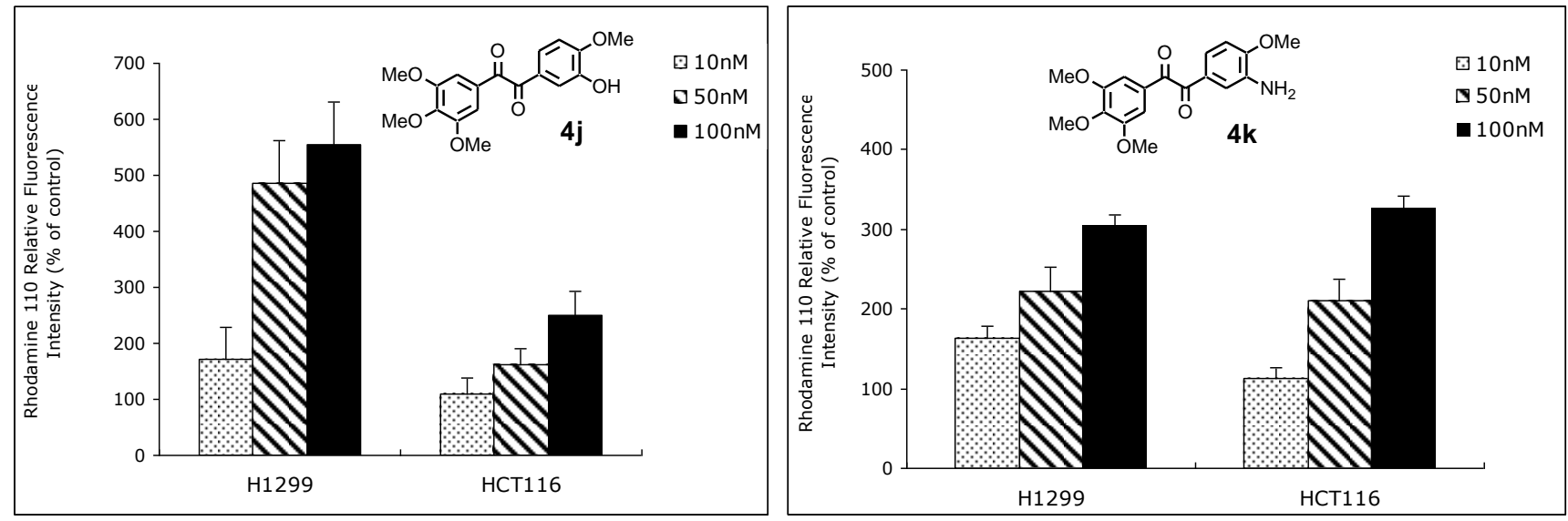

Figure 2. Apoptotic effects of benzils $\mathbf{4 j}$ and $\mathbf{4 k}$ on HCT116 and H1299 cells. Percentage of apoptotic cells induced by different concentrations of $\mathbf{4 j}$ and $\mathbf{4 k}$ (evaluation after $48 \mathrm{~h}$ of treatment). 
In conclusion, we have demonstrated that using a low loading of $\mathrm{PdI}_{2}(2 \mathrm{~mol} \%)$ in DMSO proved to be a reliable procedure for the oxidation of various functionalized diarylalkynes. This new catalytic system has proved to be high yielding, easy to handle and gave rapidly a small library of the desired benzil analogues of CA-4. Next, we have found that many of the synthesized benzil derivatives show excellent antiproliferative activities at the nanomolar level. The most active compounds $\mathbf{4} \mathbf{j}$ and $\mathbf{4 k}$ were found to be almost as potent as CA-4. It is clear from these results that the replacement of the $Z$ double bond by a 1,2dicarbonyl unit maintained a powerful anticancer activity. This study contributes to the knowledge about the SAR in the CA-4 series that may allow the design and synthesis of other derivatives having a superior anticancer activity. To this end, a series of nitrogen containing heterocycles such as imidazoles, or quinoxalines easily available from benzil derivatives is currently under investigation.

\section{Acknowledgements}

The authors gratefully acknowledge support of this project by CNRS and the MNSER for doctoral fellowships to $\mathrm{CM}$ and $\mathrm{AG}$.

\section{References and notes}

1 (a) Hadfield, J. A.; Ducki, S.; Hirst, N.; McGown, A. T. Progress in Cell Cycle Research 2003, 5, 309. (b) Attard, G.; Greystoke, A.; Kaye, S.; De Bono, J. Pathologie Biologie 2006, 54, 72. (c) Bhattacharayya, B.; Panda, D.; Gupta, S.; Banerjee, M. Med. Res. Rev. 2008, 28, 155.

2 (a) Hamel, E. Med. Chem. Rev. 1996, 16, 207. (b) Jordan, A.; Hadfield, J. A.; Lawrence, N. J.; McGown, A. T. Med. Res. Rev. 1998, 18, 259. (c) Li, Q.; Sham, H. L. Expert Opin. Ther. Pat. 2002, 12, 1663. (d) Jordan, M. A. Curr. Med. Chem. 2002, 2, 1.

3 (a) Jordan, M. A.; Wilson, L. Nat. Rev. Cancer 2004, 4, 253. (b) Siemann, D. W.; Bibby, M. C.; Dark, G. G.; Dicker, A. P.; Eskens, F. A. L. M.; Horsman, M. R.; Marme, D.; LoRusso, P. M. Clin. Cancer Res. 2005, 11, 416. (c) Siemann, D. W. Vascular-Targeted Therapies in Oncology; John Wiley \& Sons: New York, 2006.

4 (a) Pettit, G. R.; Singh, S. B.; Niven, M. L.; Hamel, E.; Schmidt, J. M. J. Nat. Prod., 1987, 50, 119. (b) Pettit, G. R.; Singh, S. B.; Hamel, E.; Lin, C. M.; Alberts, D. S.; GarciaKendall, D. Experientia 1989, 45, 209.

5 (a) McGown, A. T.; Fox, B. W. Anti-Cancer Drug Des. 1989, 3, 249. (b) Aleksandrzak, K.; McGown, A. T.; Hadfield, J. A. Anti-Cancer Drugs, 1998, 9, 545.

6 Pettit, G. R.; Singh, S. G.; Boyd, M. R.; Hamel, E.; Pettit, R. K.; Schmidt, J. M.; Hogan, F. J. Med. Chem. 1995, 38, 1666.

7 Oshumi, K.; Nakagawa, R.; Fukuda, Y.; Hatanaka, T.; Tsuji, T. J. Med. Chem. 1998, 41, 3022.

8 (a) Tozer, G. M.; Kanthou, C.; Baguley, B. C. Nat. Rev. Cancer 2005, 5, 423. (b) Tozer, G. M.; Kanthou, C.; Parkins, C. S.; Hill, S. A. Int. J. Exp. Pathol. 2002, 83, 21.

9 Patterson, D. M.; Rustin,; G. J. S. Drugs of the Future 2007, 32, 1025.
10 (a) Lippert, J. W. Bioorg. Med. Chem. 2007, 15, 605-615. (b) Patterson, D. M.; Rustin, G, J. S. Clinical Oncology 2007, 19, 443.

11 For a review, see: Tron, G. C.; Pirali, T.; Sorba, G.; Pagliai, F.; Dusacca, S.; Genazzani, A. A. J. Med. Chem. 2006, 49, 3032 .

12 (a) Hadfield, J. A.; McGown, A. T. Synth. Commun., 1998, 28, 1421. (b) Lin, C. M.; Singh, S. B.; Chu, P. S.; Dempcy, R. O.; Schmidt, J. M.; Pettit G. R.; Hamel, E. Mol. Pharmacol. 1998, 34, 200. (c) Nandy, P.; Banerjee, S.; Gao, H.; Hui M. B. V.; Lien, E. J. Pharm. Res. 1991, 8, 776.

13 (a) Pettit, G. R.; Toki, B.; Herald, D. L.; Verdier-Pinard, P.; Boyd, E.; Hamel, M. R.; Pettit, R. K. J. Med. Chem. 1998, 41, 1688. (b) Liou, J.-P.; Chang, C.-W.; Song, J.-S.; Yang, Y.-N.; Yeh, C.-F.; Tseng, H.-Y.; Lo, Y.-K.;. Chang, Y.-L; Chang, C.-M.; Hsieh, H.-P. J. Med. Chem. 2002, 45, 2556. (c) Liou, J.-P.; Chang, J.-Y.; Chang, C.-W.; Chang, C.-Y.; Mahindroo, N.; Kuo, F.-M.; Hsieh, H.-P. J. Med. Chem. 2004, 47, 2897.

14 Ducki, S.; Forrest, R.; Hadfield, J. A.; Kendall, A.; Lawrence, N. J.; McGown, A. T.; Rennison, D. Bioorg. Med. Chem. Lett. 1998, 8, 1051.

15 (a) Provot, O.; Giraud, A.; Peyrat, J.-F.; Alami, M.; Brion, J.D. Tetrahedron Lett. 2005, 46, 8547. (b) Giraud, A.; Provot, O.; Hamze, A.; Brion, J.-D.; Alami, M. Tetrahedron Lett. 2008, 49, 1107.

16 Giraud, A.; Provot, O.; Peyrat, J.-F.; Alami, M.; Brion, J.-D. Tetrahedron 2006, 62, 7667.

17 Mousset, C.; Provot, O.; Hamze, A.; Bignon, J.; Brion, J.-D.; Alami, M. Tetrahedron 2008, 64, in press.

18 (a) Sonogashira, K.; Tokai, Y.; Hagihara, N. Tetrahedron Lett., 1975, 4467. (b) Alami, M.; Ferri, F.; Linstrumelle, G. Tetrahedron Lett. 1993, 34, 1433. (c) Alami, M.; Ferri, F.; Gaslain, Y. Tetrahedron Lett. 1996, 37, 57.

19 Spectral data for representative compounds: 4j: IR (neat, $\mathrm{cm}^{-1}$ ) 3378, 1654, 1605, 1578, 1501, 1471, 1418, $1341,1311,1290,1241,1154,1120,1004 .{ }^{1} \mathrm{H}$ NMR $\left(\mathrm{CDCl}_{3}\right.$, $200 \mathrm{MHz}) \delta 3.87(\mathrm{~s}, 6 \mathrm{H}), 3.93(\mathrm{~s}, 3 \mathrm{H}), 3.97$ (s, 3H), 5.76 (brs, $1 \mathrm{H}), 6.90(\mathrm{~d}, 1 \mathrm{H}, J=8.4 \mathrm{~Hz}), 7.20(\mathrm{~s}, 2 \mathrm{H}), 7.49(\mathrm{dd}, 1 \mathrm{H}, J=$ $8.4 \mathrm{~Hz}, J=2.1 \mathrm{~Hz}), 7.55(\mathrm{~d}, 1 \mathrm{H}, J=2.1 \mathrm{~Hz}), 6.90(\mathrm{~d}, 1 \mathrm{H}, J=$ $8.4 \mathrm{~Hz}) .{ }^{13} \mathrm{C} \mathrm{NMR}\left(\mathrm{CDCl}_{3}, 75 \mathrm{MH}\right) \delta 56.0\left(\mathrm{CH}_{3}\right), 56.3$ $\left(2 \mathrm{CH}_{3}\right), 61.0\left(\mathrm{CH}_{3}\right), 107.1(2 \mathrm{CH}), 110.3(\mathrm{CH}), 115.4(\mathrm{CH})$, $123.3(\mathrm{CH}), 126.6(\mathrm{C}), 128.3(\mathrm{C}), 144.0(\mathrm{C}), 148.6(\mathrm{C}), 153.3$ (2C), 154.1 (C), 193.6 (C), 194.0 (C). m.p. $=153-154{ }^{\circ} \mathrm{C}$. Anal. Calcd for $\mathrm{C}_{18} \mathrm{H}_{18} \mathrm{O}_{7}$ : C, 62.42; H 5.24. Found: C, 62.29; H 5.11.

4k: IR (neat, $\mathrm{cm}^{-1}$ ) 3400, 1668, 1651, 1519, 1502, 1445, 1412, 1340, 1304, 1240, 1123, 1018. ${ }^{1} \mathrm{H}$ NMR $\left(\mathrm{CDCl}_{3}, 200\right.$ $\mathrm{MHz}) \delta 3.87$ (s, 6H), 3.93 (s, 3H), $6.82(\mathrm{~d}, 1 \mathrm{H}, J=8.2 \mathrm{~Hz})$, 7.20 (s, 2H), 7.33 (dd, $1 \mathrm{H}, J=8.2 \mathrm{~Hz}), J=2.2 \mathrm{~Hz}), 7.37$ (d, $1 \mathrm{H}, J=2.2 \mathrm{~Hz}) .{ }^{13} \mathrm{C} \mathrm{NMR}\left(\mathrm{CDCl}_{3}, 75 \mathrm{MH}\right) \delta 55.7\left(\mathrm{CH}_{3}\right)$, $56.2\left(2 \mathrm{CH}_{3}\right), 61.0\left(\mathrm{CH}_{3}\right), 107.0(2 \mathrm{CH}), 109.5(\mathrm{C}), 114.8$ $(\mathrm{CH}), 123.0(\mathrm{CH}), 126.3(\mathrm{C}), 128.2(\mathrm{C}), 136.7(\mathrm{C}), 143.8(\mathrm{C})$, 153.2 (2C), $153.6(\mathrm{CH}), 193.5$ (CO), 193.8 (CO). m.p. = 146$147{ }^{\circ} \mathrm{C}$. SM $\left(\mathrm{ESI}^{+}, \mathrm{m} / z, \%\right): 368(\mathrm{M}+\mathrm{Na}, 100)$. Anal. Calcd for $\mathrm{C}_{18} \mathrm{H}_{19} \mathrm{NO}_{6}$ : $\mathrm{C}, 62.60 ; \mathrm{H} 5.55 ; \mathrm{N}$ 4.06. Found: $\mathrm{C}, 62.39 ; \mathrm{H}$ 5.41 ; N 3.96.

20 (a) Cushman, M.; Nagarathnam, D.; Gopal, D.; He, H. M.; Lin, C. M.; Hamel, E. J. Med. Chem. 1991, 34, 2579. (b) Cushman, M.; Nagarathnam, D.; Gopal, D.; He, H .M.; Lin, C. M.; Hamel, E. J. Med. Chem. 1992, 35, 2293.

21 Zavala, F.; Guénard, D.; Robin, J.-P.; Brown, E. J. Med. Chem. 1980, 23, 546. 